\title{
Autonomy and Accountability in Higher Education An Indian Perspective
}

\author{
Dr. M.M. Gandhi \\ Principal, Professor and Head PG Department of Commerce and Management, Jaysingpur College of Arts, \\ Commerce, Science and Computer Science (UG \& PG) A/post Jaysingpur-416 101, Dist. Kolhapur, \\ Maharashtra
}

\begin{abstract}
This comprehensive paper is an attempt to provide an overview of the design, development and implementation of and the mechanism set up to ensure the fulfillment of the objective laid down in the scheme of the grant of Autonomy vis-à-vis the Status of Autonomy in India. This paper highlights very recent initiatives pertaining to the grant of Autonomy vis-à-vis the Status of Autonomy in India. This paper attempts to develop an overview of the initiatives of the Ministry of Human Resource Development of Government of India [MHRD], University Grants Commission of India [UGC]. This paper critical analyzes (a) the steps taken for grant of Autonomy, (b) perception, attitude and approach of higher educational institutions towards the concept of the Autonomy in India, on the background of the criteria, goals and objectives of higher education set out by the $M H R D$ and $U G C$.
\end{abstract}

Key words: Autonomy, Accountability, perception, attitude, approach, criteria, goals and objectives of higher education, MHRD, UGC.

\section{Introduction}

(1.1) Looking back, during the last six decades, the Indian higher education system had undergone many important changes; the most significant being its unprecedented growth and its consequent transformation from an elite system to a mass system.

(1.2) The Sphere of higher education has been marked by a phenomenal expansion during the five decades, after Independence. Today, Higher education in India is imparted through 620 Universities and equivalent institutions. Total number of Colleges in the country is about 35,000 .

(1.3) The higher education system in India includes both private and public universities. Public universities are supported by the Government of India and the state governments, while private universities are mostly supported by various bodies and societies. Universities in India are recognized by the University Grants Commission (UGC), which draws its power from the University Grants Commission Act, 1956. In addition, 16 Professional Councils are established, controlling different aspects of accreditation and coordination. The types of universities controlled by the UGC include Central universities, State universities, Deemed universities and Private universities In addition to these universities, other institutions are granted the permission to autonomously award degrees, and while not called "university" by name, act as such. They usually fall under the administrative control of the Department of Higher Education. In official documents they are called "autonomous bodies", "university-level institutions", or even simply "other central institutions", (Wikipedia, 2013).

(1.4) The different commissions and committees that have examined the Indian higher education system, after independence, have identified the maladies that affect it and have also suggested remedies. However, we have failed to follow up on the recommendations. The maladies identified by the Kothari Commission over three decades ago still exist. The latest example of our indifferent approach is the half-hearted manner in which the Programme of Action, 1992 is being implemented.

(1.5) The Kothari Commission emphasized that the proper sphere of Institution autonomy is in three fields; (1) Selection of students, (2) Appointment and promotion of teachers, (3) Determination of courses of study, methods of teaching and selection of areas and problems of research.

(1.6) The National Policy on Education visualized that higher education should become dynamic as never before. One of the main features of the programmes and strategies to impart the necessary dynamism to the higher education system consist of the Development of Autonomous Colleges and Departments. The system of affiliated colleges does not provide autonomy to deserving colleges to frame curricula, courses of studies, or their own system of evaluation. 
(1.7) The apathy of the Union Government as well as State Governments has been well known to the Higher Educational Planners and Academicians and even sometimes helpless Governors of the States, who are de jure Chancellors of Universities, established by State enactments.

\section{The Affiliation System and Autonomous Colleges}

(2.1) Many of the ills of Indian higher education can be attributed to the system of affiliation. Most conventional Indian universities are teaching-cum-affiliating; and some of the larger universities have more than 600 colleges affiliated to them. The colleges have common syllabi and the students appear for a common examination usually conducted at the end of the year. For many universities the conduct of examination has become the most important administrative function.

(2.2) The affiliating system was devised to regulate and standardize the quality of education. But with the tremendous increase in the number of institutions the system has become counter-productive. Because of it some sub-standard colleges serenely ride piggyback on the reputation of the mother institution. The affiliating system is a drag on the better institutions that would otherwise regularly revise and updates their curricula and introduces innovative programmes. In order to allow the growth of colleges that had the desire to move ahead the concept of autonomous colleges was introduced about a decade back. It allows the college to have autonomy as regards academic matter. Management, teachers and students all look upon this innovation with suspicion. There is clearly a need for dialogue amongst all concerned so that a conductive environment can be created. Many educationists feel that the programme of granting to the colleges needs to be vigorously pursued, even to the extent of making every colleges autonomous and responsible for itself.

\section{Autonomy : A Myth or a Reality}

(3.1) Autonomy of institutions broadly emphasizes (a) freedom to function to achieve academic excellence and (b) freedom to administer the institution through its own rules and regulations. Such autonomy has now become a veritable myth on account of (1) too much linkage with political powers of the state, and (2) financial constraints faced by the institutions.

(3.2) Many states have come to apply more control on autonomous functioning of universities \& colleges by various means and methods. Financial aid has become most powerful instruments in the hands of state government to curtail the autonomy of the University \& Colleges.

\section{UGC Scheme of Autonomous Colleges}

The UGC has a scheme under which a college declared autonomous by is affiliating university, is fully accountable for the content and quality of education it imparts. Such a college is also responsible for setting its own examination paper and for the conduct of examinations. The college evaluates the students for the award of degrees which will be accepted by the parent university. An autonomous college is provided financial assistance per annum depending upon the course and the level of education imparted by it.

Following Tables provide the latest data and status of Autonomous Institutions in India.

Table - I

Current Status of List of Approved State-wise Autonomous Colleges declared by University Grants

Commission, New Delhi, India

As on 30 May 2013

\begin{tabular}{|c|l|l|l|}
\hline $\begin{array}{c}\text { SrNo } \\
\text { for } \\
\text { State }\end{array}$ & Name of the State & $\begin{array}{c}\text { No. of Universities having } \\
\text { Autonomous Colleges }\end{array}$ & Autonomous Colleges \\
\hline $\mathbf{0 1}$ & ANDHRA PRADESH & $\mathbf{1 3}$ & $\mathbf{7 0}$ \\
\hline 02 & ASSAM & 01 & 01 \\
\hline 03 & BIHAR & 01 & 01 \\
\hline 04 & CHHATTISGARH & 02 & 10 \\
\hline 05 & GUJRAT & 02 & 02 \\
\hline 06 & HARYANA & 01 & 01 \\
\hline 07 & HIMACHAL PRADESH & 01 & 05 \\
\hline 08 & JAMMU \& KASHMIR & 02 & 02 \\
\hline 09 & JHARKHAND & 01 & 05 \\
\hline $\mathbf{1 0}$ & KARNATAKA & $\mathbf{0 8}$ & $\mathbf{4 9}$ \\
\hline $\mathbf{1 1}$ & MADHYA PRADESH & $\mathbf{0 8}$ & $\mathbf{3 5}$ \\
\hline $\mathbf{1 2}$ & MAHARASHTRA & $\mathbf{0 8}$ & $\mathbf{2 8}$ \\
\hline 13 & NAGALAND & 01 & 01 \\
\hline 14 & ORISSA & 06 & 37 \\
\hline 15 & PONDICHERY & 01 & 02 \\
\hline 16 & PUNJAB & 04 & 04 \\
\hline 17 & RAJASTHAN & 02 & 03 \\
\hline
\end{tabular}


Autonomy and Accountability in Higher Education An Indian Perspective

\begin{tabular}{|l|l|l|c|}
\hline $\mathbf{1 8}$ & TAMILNADU & $\mathbf{1 2}$ & $\mathbf{1 5 5}$ \\
\hline 19 & UTTAR PRADESH & 07 & 11 \\
\hline 20 & UTTARAKHAND & 02 & 04 \\
\hline 21 & WEST BENGAL & 02 & 07 \\
\hline $\mathbf{2 1}$ & GRAND TOTAL & $\mathbf{8 5}$ & $\mathbf{4 4 1}$ \\
\hline
\end{tabular}

Source: UGC Statistical data, 2013, List of Autonomous Colleges: Status as on 30.05.2013: published on website, Retrieved From:- www.ugc.ac.in/oldpdf/colleges/autonomous_collegeslist.pdf ;

Table - II

Current Status of State-wise List of Autonomous

Higher Educational Institutes [other than Colleges] : As on 31-12-2012

\begin{tabular}{|l|l|l|}
\hline SrNo & \multicolumn{1}{|c|}{ Name of the State } & $\begin{array}{l}\text { No. of Autonomous } \\
\text { Higher Educational Institutes* }\end{array}$ \\
\hline 01 & ANDHRA PRADESH & $\mathbf{0 5}$ \\
\hline 02 & ASSAM & $\mathbf{0 3}$ \\
\hline 03 & BIHAR & $\mathbf{0 5}$ \\
\hline 04 & CHHATTISGARH & $\mathbf{0 2}$ \\
\hline 05 & DELHI & $\mathbf{0 3}$ \\
\hline 06 & GUJARAT & $\mathbf{0 6}$ \\
\hline 07 & HARYANA & $\mathbf{0 2}$ \\
\hline 08 & HIMACHAL PRADESH & $\mathbf{0 2}$ \\
\hline 09 & JAMMU \& KASHMIR & $\mathbf{0 2}$ \\
\hline 10 & JHARKHAND & $\mathbf{0 3}$ \\
\hline 11 & KARNATAKA & $\mathbf{0 6}$ \\
\hline 12 & KERALA & $\mathbf{0 3}$ \\
\hline 13 & MADHYA PRADESH & $\mathbf{0 8}$ \\
\hline 14 & MAHARASHTRA & $\mathbf{0 4}$ \\
\hline 15 & MEGHALAYA & $\mathbf{0 1}$ \\
\hline 16 & ORISSA & $\mathbf{0 4}$ \\
\hline 17 & PUNJAB & $\mathbf{0 5}$ \\
\hline 18 & RAJASTHAN & $\mathbf{0 6}$ \\
\hline 19 & TAMILNADU & $\mathbf{0 5}$ \\
\hline 20 & TRIPURA & $\mathbf{0 1}$ \\
\hline 21 & UTTAR PRADESH & $\mathbf{0 6}$ \\
\hline 22 & UTTARAKHAND & $\mathbf{0 3}$ \\
\hline 23 & WEST BENGAL & $\mathbf{0 5}$ \\
\hline & GRAND TOTAL & $\mathbf{9 0}$ \\
\hline
\end{tabular}

* The List of Institutes includes Institutes of National Importance and some select Universities created by Central and State enactments

Source: Wikipedia, the free encyclopediahttp://en.wikipedia.org/wiki/List_of_autonomous_higher_ education_institutes_in_India\#cite_ref-9;

\section{Autonomy and Accountability}

(5.1) Along with autonomy, another important element is accountability, which is the kingpin of democratic University administration. It is not only regulatory and punitive in its content. It has a positive and promotional goal. That is, adequate administrative performance as per the objectives and structure of a University is to be ensured.

(5.2) Autonomy and Accountability are really two sides of the same coin. Any complex task of a continuing nature which requires the participation of different people at different places, requires a management system which can determine and assign responsibilities, laying down who will do what, where, when, etc., and also the freedom to take the initiative without interference from outsides who are not accountable to the management for the achievement of organizational objectives. Large industrial or commercial under-takings, multi-nationals and other enterprises, in respect of which every step or situation cannot be predicted, allow their regional boards and managers considerable freedom of action. Generally the degree of interference from the higher authorities in the functioning of a lower formation is determined partly by the nature of the task and partly also by the latter's record of performance.

(5.3) Accountability has both a broader and narrower connotation. In a broad sense, it may refer to the returns to society for the investment made in maintaining Universities. The returns are measured as costs/benefits or increase in efficiency of manpower engaged in different vocations or professions. There are also the overall benefits to society, which are diffused. In a narrow sense, it refers to answerability to the superior authority for implementation and achievement. In short, accountability demands carrying out administrative operation with economy, efficiency and effectiveness.

(5.4) Financial accountability of a College is important because in the public view, the taxpayer has a prerogative to demand proof of effective programme or performance of excellence of the College product or its effect on society. It underlines effectiveness of all financial expenditures on a College. At the same time, in the name of accountability, performance should not become the prisoner of non-decision. 
(5.5) In the context of College finances, accountability may be distinguished with reference to (1) Procedures, (2) Endresult physical product (3) Contribution to knowledge and societal use and (4) End-result educational product.

(5.6) For procedural accountability, what the Grant-in-aid, University Act, Statutes, and rules of purchase prescribe, the relevant authority for giving sanctions and the legal aspect become an answer adjunct to it. In the case of end-result product, the final outcome by way of physical assets created by University expenditure funded by grants or donations is the measure.

\section{Minimal Requirements of Autonomy and Accountability}

It is necessary to identify the prerequisites of functional autonomy without which one cannot expect the colleges to perform the tasks assigned to them. It is also necessary to establish a broad consensus on what should be regarded as the minimal requirement of accountability vis-à-vis the College system.

To mention only the routine functions, ignoring the inescapable socio-cultural and economic responsibilities, it is selfevident that every College has to ensure that :

it will admit students as per a pre-determined schedule, only on the basis of objective, transparent and credible criteria; it will lay down and, from time to time, update syllabi and curricula, keeping in view the general levels of competence of students at the entry point and the conceptual comprehension, methodological skills and factual information which they must acquire to obtain employment commensurate with their degrees;

class and course work proceeds according to a given time table;

appraisal of the levels of achievements of students vis-à-vis the prerequisites laid down in the syllabi, etc. would be undertaken well in time through processes which would demonstrably preclude favoritism and corruption :

the grading awarded to examinees would be such as to command credibility among monitoring and funding agencies, other institutions and employers;

an environment for learning would be created which would ensure that the general body of students would become actively involved with the pursuit of knowledge, so that there would be very little 'wastage and stagnation';

the composition of the staff and of the student body and the general environment would discourage inbreeding the parochialism, and ensure that personnel at all levels felt accountable for the performance of their duties in a responsible position; and

there is adherence to reasonable norms in the matter of optimal utilization of staff, equipment and infrastructure, professional encouragement, financial discipline and grievance redressal.

Complete autonomy to colleges raises the question of financing of college education. Today except for the fees paid by the students and a small amount of endowment fund and other sources of receipts of the colleges, the state and central governments and local authorities meet the overwhelming proportion of the current expenditure. There is no reason why all these institutions, irrespective of their strength and quality should be supported from public funds. this of course does not mean that the state should provide no funds for higher education. Indeed, the better way for providing funds for higher education is to make widespread provision for scholar ships and loans to students submitted to different educational institutions. The institutions should charge full fees and the student can choose the institution of his preference. But, in the first place, such sharp and sudden change can create great dislocation and confusion. Mor eover, the government may like to keep an eye on the way the institutions are likely to raise and use their resources. For this purpose, it is advantageous if the government meets a part of the costs.

\section{Financial Autonomy and Accountability}

(7.1) Efficient functioning of an institution is hedged, inter alia, on the side by financial inadequacy coupled with lack of autonomy and on other side by centralization of financial and administrative powers. While the former emanates from the funding agency, mostly the Government, State or Central the latter is anchored to the top administrative layer of the institution. The one is by design and the other is by bureaucratic choice in an otherwise free academic environment. Consequently, when an institution has an ever-expanding role, the pervasiveness and impact of fund shortage and financial centralization are both getting more extensive and intensive on its performance or accomplishment. The crucial test of efficiency and effectiveness of Institution administration lies in the fulfillment of the stipulated objectives of higher education. Its policy must effectuate into successful programmes and consistently seek to strive for them, failing which, ends up in an administrative abortion.

(7.2) College administration functions may broadly be classified as (1) service function (2) protective function (3) primitive function and (4) preservative function. Service function is basic and it is to sub-serve the requirement of students, teaching and research. To this is to be added to welfare aspect also. The protective functions refer to safeguarding the rights and privileges of all members of the College community. Recruitment, admission, service matters, health delivery system, obligatory responses and the like are included. The primitive function is directed at realizing self-realization for all members facilitating enjoyment of academic freedom and cultures. The Preservative function covers its role as a trustee of the resources and contributions that are to be preserved for passing on to the future generations. Through these functions, it may be said that a college strives to facilitate the creation of academic environment for the university community in which individuals may achieve excellence in the pursuit of knowledge and their personality development.

(7.3) The financial autonomy refers to the governance of College finances by its own Management. College should function without any outside intervention or pressures and should not involve itself in any power game from individuals or groups. Together with academic freedom, financial autonomy is an essential requirement of any progressive University.

(7.4) Keeping up to the financial commitments at the Government level and providing financial flexibility in matters of promotion on merit, research needs, student programmes are necessary. Changes are called for above the College level in terms of decentralization of financial powers among the functionaries like the Secretary, Director, Joint Director in the education department. Similarly, decentralization of financial powers and enhancement of such powers where they exist now 
is imperative at the U.G.C. level. Any reform, which has figured in recent discussion, is of no use if it is not accompanied by adequate delegation of financial powers.

(7.5) At the College level, decentralization of financial powers both horizontally and vertically is necessary. The basic tests in deciding the levels and adequacy should be: (1) whether it facilitates quick decision making and eliminates delays? (2) Whether the felt needs of the various segments are properly comprehended? (3) Whether it involves greater co-operation than resistance? (4) What impact it has on the end-result? (5) How soon can the end-result be achieved? (6) Will it meet the standards of expertise where needed? (7) Is there the requisite administrative support? (8) If adequate administrative support is missing, can it be provided by redeployment of administrative staff? (9) What type of maintenance and reporting system is to be developed?

\section{Summing Up}

(8.1) The concept of autonomy or autonomous colleges or accountability thereof can be systematically dovetailed in the aforesaid issues. It seems desirable to reiterate that the whole exercise will serve no purpose if Union Government and State Governments keep enjoying their control through its departments.

(8.2) Some of the aforesaid key issues in the process of granting autonomy and ensuring accountability have been discussed in this paper. These issues are to be resolved in progressive manner, with definite and meaningful action plan for the same.

\section{Reference Material and Acknowledgement}

The author has extensively used several private and official document, articles, research work, reviews and books while preparing this paper. The entire list of reference materials is given in alphabetical order. Grateful acknowledgement is made to all known and unknown (in case of official documents) authors.

\section{References}

[1]. Alexander Dr. P. C., Governor \& Chancellor of Universities in Maharashtra, his speech in the concluding function of the Golden Jubilee celebrations and foundation day of Pune Univ., (Feb. 10, 1999), Pune, Indian Express, Feb. 11, 1999, Pune News Line, p 1;

[2]. Alexander Dr. P. C., Governor \& Chancellor of Universities in Maharashtra, his speech in the inaugural address (Dec. 10, 1998), $19^{\text {th }}$ Conference MFACPA, Nagpur, Indian Express, Dec. 11, 1998, p 1-3;

[3]. Desai Armaity S UGS Chairperson (1997) Inaugrual address (7/2/1997) NIAS Bengalore, Indian Express Oct. 8, 1997 P 4;

[4]. Gandhi Dr. M M, (1993) 'Maharashtra Universities Bill 1992' University News, Vol.XXX1, Jan 25, 1993, New Delhi;

[5]. Gandhi Dr. M M, (1997) 'Reform \& Development of Higher Education in India - Some Key Issues', Souvenir of $18^{\text {th }}$ Annual State Conference of Principals (1997), Aurangabad;

[6]. Gandhi Dr. M M, (1998), 'Implications of Unplanned \& Unmotivated Growth of Higher Education in India', College Post - the ICF Journal, Vol.3 No.1, p 3-7;

[7]. Govt. of India (1966) Report of the Education Kothari Commission (1964-66) : Education and National Development, Delhi Part 1992 PP Part II;

[8]. Govt. of India (1985) Challenge of Education Policy Perspective, New Delhi;

[9]. Govt. of India (1986) National Policy on Education 1986 GOI N., Delhi;

[10]. Govt. of India (1989) Towards an Enlightened and Human Society, Reports of the Committee for Review of the National Policy on Education 1986, GOI New Delhi;

[11]. Govt. of India (1992) Programme of Action 1992 National Policy on Education, 1986, revised 1992 (Reprinted by UGC) New Delhi p 250;

[12]. Govt. of India (1997) Govt. subsidies in India, Discussion Paper Department of Economic Affairs, Ministry of Finance p 20;

[13]. Govt. of Maharashtra (1992) Report of Committee constituted to recommend revised draft of the proposed Non Agricultural Universities Bill 1992;

[14]. Jayalaxmi Indireasan (1992) TOM for Edn, Univ. News, AIU, New Delhi;

[15]. Jaykar I M (1987), 'Govt. Leave the College Alone' Indian Express Dec. 2, 1987;

[16]. Kaul JN (1988) Governance of Universities Autonomy of the University Community, New Delhi : Abhinav p 308;

[17]. Maharashtra Universities Acts 1974, 1982, 1989;

[18]. Maharashtra Universities Act 1994;

[19]. Mitra NL (1992) Statutory Structure of University Administrations \& Functions, and its consequences University New July, 20, 1992;

[20]. Mohanty J (1993) Dynamics of Higher Education in India, Dep and Deep Publn. New Delhi P 419;

[21]. Poona University Act 1974;

[22]. Power KB (1996) Unit Costs in Higher Education AIU New Delhi P 14;

[23]. Power KB (1997), Higher Education in India since Independence : Restrospect and Future options, AIU, New Delhi p 5-21;

[24]. Power KB Panda SK and Sharma TC (1995) Unit Costs of Education in Indian Universities AIU, New Delhi P 34;

[25]. Report on Financial Constraints and University Education in Maharashtra, (1989) submitted by Dr. M G Bakare (the then VC Univ. of Nagpur), to Govt. of Maharashtra, Planning Board, Mumbai;

[26]. Report on the Proceeding of the Annual Vice-Chancellors' Conference, (held on 8.10.1991 at Univ. of Kerala), 'Decentralization of Higher Education System', AIU publn., New Delhi;

[27]. Tilak JBG, Pricing Higher Education, UGC, Occassional Paper No. 2 UGC New Delhi p 6-8;

[28]. UGC Annual Reports 1971 to 2012;

[29]. UGC (1990) Report of the UGC Committee (Gnanam Committee) Towards New Educational Management, New Delhi, p 82-84. 